\title{
Trade in Asian elephant ivory in Sri Lanka
}

\author{
Charles Santiapillai, Ajith Silva, Champika Karyawasam, Shameema Esufali, Salila Jayaniththi, Mano \\ Basnayake, Vasantha Unantenne and S. Wijeyamohan
}

\begin{abstract}
Elephants Elephas maximus have declined in range and number in the wild in Sri Lanka, from c. 12,000 at the turn of the nineteenth century to $c .4000$ today. While in the distant past the decline in elephant numbers was due largely to indiscriminate killing by sportsmen and trophy hunters, today elephants are being killed primarily because they interfere with agriculture. Human-elephant conflicts have increased substantially in the recent past and ivory poaching has become a byproduct of such conflicts. Elephant tusks have been used traditionally in the ivory-carving industry in Sri Lanka since the time of the ancient kings. Until the turn of the century, very little ivory was imported from Africa because there was a plentiful supply of tuskers locally available. Sri Lankan ivory carvers started to use African ivory in 1910. Today ivory and fake-ivory products are sold openly to
\end{abstract}

tourists in some 86 shops in the island. Before the listing of the African elephant in Appendix I of the Convention on International Trade in Endangered Species (CITES), the value of raw ivory in Sri Lanka used to be $\$$ US228-285 per $\mathrm{kg}$. After the listing, the price fell to \$US72 per $\mathrm{kg}$, reflecting a drastic drop in the demand for ivory from tourists. Many ivory carvers have switched to other jobs or are using substitutes (such as bone and horn) to produce fake-ivory carvings. Only about 7.5 per cent of bulls in Sri Lanka are tuskers and they are under poaching pressure outside protected areas. Given the rarity of tuskers in Sri Lanka, promotion of trade in ivory products, even locally, may pose a serious threat to their long-term survival in the wild.

Keywords Asian elephant, CITES, ivory, poaching, wildlife trade.

\section{Introduction}

The wild elephant population in Sri Lanka has declined from an estimated 12,000 at the turn of the nineteenth century to c. 4000 individuals today. This trend is also apparent in the number of elephants in captivity, which declined from 670 in 1955 to 316 by 1995 (Chin et al., 1998). In the past the decline in the wild population was due largely to the wholesale slaughter of elephants by sportsmen and trophy hunters when forests were being cleared to make way for coffee, and later tea, plantations, especially in the hills. More recently a substantial number of elephants have been killed in encounters with poachers and farmers. On average,

Charles Santiapillai (corresponding author), Department of Zoology, University of Peradeniya, Sri Lanka. E-mail: csanti@slt.lk

Ajith Silva, Champika Karyawasam, Shameema Esufali, Salila Jayaniththi, Mano Basnayake and Vasantha Unantenne Postgraduate Institute of Science, University of Peradeniya, Sri Lanka.

S. Wijeyamohan Department of Biology, University of Jaffna, Vavuniya Campus, Sri Lanka.

Received 6 March 1998. Accepted 7 September 1998 c. 100-120 elephants are being lost annually in Sri Lanka today-almost double the number lost between 1950 and 1970 (Santiapillai, 1994).

Ivory carving in Sri Lanka is an ancient tradition. Kandyan ivory carvers were well known for their exquisite work and their trade enjoyed royal patronage during the Kandyan period between 1597 and 1815. Even after the collapse of the Kandyan Kingdom, ivory carving flourished in response to the demands of the Sinhalese aristocracy. This trade in ivory products was sustainable, given the relatively large population of elephants, including tuskers, in the wild. The introduction of coffee, and later tea, into the hill country by the British Colonial administration resulted in a massive dislocation and destruction of elephants in Sri Lanka.

\section{Decline of elephants}

Elephants were so numerous in Sri Lanka that until about 1830 their destruction was encouraged by the government (Storey, 1907) and rewards were paid for any that were killed (Baker, 1853). In this manner, no fewer than 5000 elephants were systematically eliminated within a period of 10 years (Tennent, 1867). 
Storey (1907) credits a Major Rogers with the slaughter of 1400 elephants. Rogers was killed by lightning and, strangely, his grave was struck by lightning several times (Hensoldt, 1895). In addition to such losses, elephants were also captured in large numbers and exported to India to grace the Royal Courts (Marshall, 1846). Between 1863 and 1899, a total of 2190 elephants were exported to western zoos alone (Clark, 1901). In addition to live animals, ivory was exported to India: between 1879 and 1883 c. $1000 \mathrm{~kg}$ of raw ivory were exported annually from Sri Lanka (van Heurn, 1929). Even as recently as 1930, some local ivory was exported to Japan in response to a preference by Japanese carvers for Sri Lanka elephant ivory.

The Asian elephant was given full protection in 1937 (under the Fauna and Flora Protection Ordinance No. 2) and large-scale slaughter of elephants came to an end in Sri Lanka. However, the pursuit of bull elephants with tusks by sportsmen, game hunters and poachers had been so intense in the past that tuskers now constitute a very small proportion of the population: only 7.5 per cent of bulls are tuskers (Hendavitharana et al., 1994). The current average adult male: female ratio appears to be $1: 3$ (Hendavitharana et al., 1994), but in north-central Sri Lanka, where incidents of human-elephant conflict are very high, the adult male:female ratio is about $1: 7$. In a polygynous species such as the elephant, the sex ratio will naturally be female-biased. However, the selective hunting of males would exacerbate this situation, as seen in the Periyar Tiger Reserve in southern India, where heavy poaching of tuskers has skewed the adult male: female ratio from 1:6 in 1969 to $1: 101$ in 1997 (Ramakrishnan et al., 1998). In Sri Lanka, the few tuskers that remain are extremely vulnerable to poaching. In 1992, at least eight tuskers were killed (Jayewardene, 1994). More recently, organized gangs of poachers operating in the North Central Province are known to have killed six tuskers for their ivory (Anon., 1996). Unconfirmed reports indicate that about 50 elephants were killed by Tamil separatists and land mines between January and August 1990 in the ongoing civil war in the northern and eastern parts of Sri Lanka (Wanigasundara, 1990).

\section{Use of local and African ivory in Sri Lanka}

In 1979, according to Martin \& Martin (1990), Sri Lanka had about 107 artisans working ivory, of which 45 operated in and around the old town of Galle (Fig. 1). This city still remains the centre for ivory carving. The Sri Lankan ivory-carving industry relied on the plentiful supply of tuskers that were available in the distant past. Thus, very little, if any, ivory was imported from Africa until the turn of the century. During the 1920s, an annual average of $472 \mathrm{~kg}$ was imported legally, mostly from Africa, followed by a slump until the end of World War II, when the amount imported increased to $621 \mathrm{~kg}$ per year from 1956 to 1964 (Martin \& Martin, 1990). All along there had been a small supply of ivory from the local populations of elephants in the wild, augmenting that imported from Africa. Some ivory came from the domestic stock of elephants but most locally traded ivory came from animals that were killed by poachers and irate farmers. The Department of Wildlife Conservation (DWC) used to collect the tusks from dead elephants and also confiscated ivory from poachers and traders, selling the ivory by public auction. These sales were closed in 1965 and subsequently the DWC stockpiled the ivory.

\section{Sri Lanka and CITES}

Sri Lanka is a Party to the Convention on International Trade in Endangered Species of Wild Fauna and Flora (CITES). In 1981 the DWC gave an amnesty to all people who owned elephant tusks and ivory carvings, and required them to register their stocks with the Department. Therefore, after 1981 it was illegal for anyone to own unregistered tusks or sell ivory products. However, ivory products are still being sold openly in tourist shops, together with other banned items such as marine-turtle shells. The DWC officials are empowered to confiscate these goods and prosecute the offenders but do not do so. Today, according to the DWC, there are at least 86 shops where ivory products (and at times even fake-ivory artefacts) are being sold (Table 1). Although some of the ivory could be from pre-convention stock, ivory from illegal sources is still being sold in the shops. In 1995 a small ivory-carving factory at Horana, near Colombo, was raided by DWC officials; this factory was using local ivory to make artefacts such as pendants, Buddhist and Hindu statues, and cigarette holders for sale at tourist outlets.

Although the Asian elephant was listed in Appendix I of CITES as early as June 1975, the real decline in the number of ivory craftsmen started only after the international outcry against the ivory trade and the subsequent listing of the African elephant in Appendix I at the CITES meeting in Lausanne, Switzerland in 1989. From 1990 all commercial ivory trade between member states, except for countries that took out reservations, became illegal. Many of the local ivory craftsmen changed to carving wood and horn, while some have turned their attention to producing brassware, silverware and wood carvings. Some have lost their livelihoods and have had no job-training opportunities to enable them to venture into new careers. 


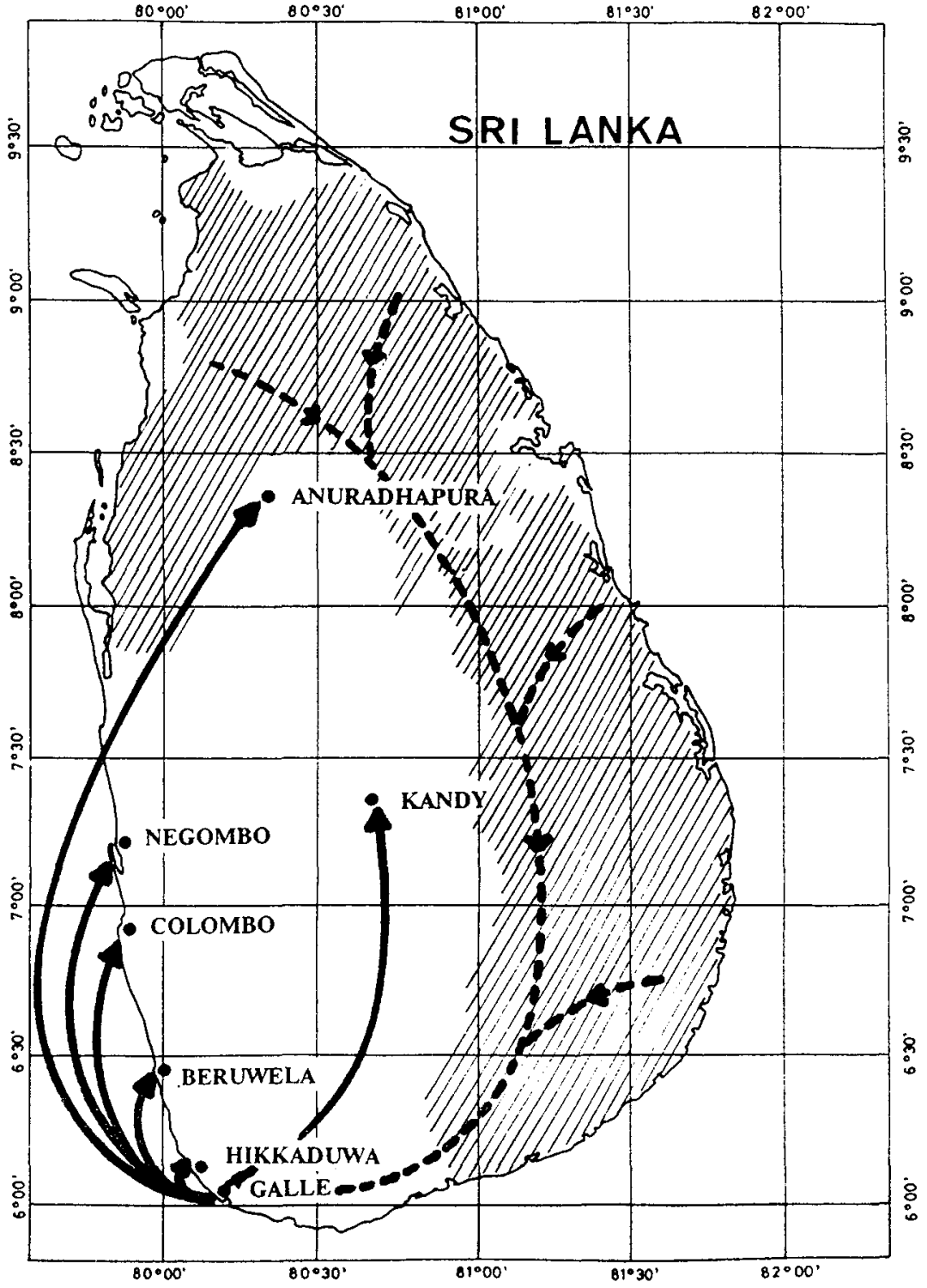

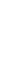

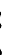

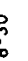

Fig. 1 Major trade routes for ivory in Sri Lanka. Solid lines indicate the flow of worked ivory; broken lines indicate the flow of raw ivory from conflict areas to the ivory-carving centre, Galle. Cross-hatched area represents the approximate range of the elephant in Sri Lanka.

\section{The current ivory trade in Kandy}

We carried out a short survey in Kandy district to investigate the status of the ivory trade. It appears that almost all the tourist shops carry some items of elephant ivory for sale and at least three shops had fake-ivory products as well. The prices given for the items found for sale are given in Table 2. Everyone we questioned claimed not to know about CITES and its implications for international trade in ivory. Nevertheless, they were all aware of the fact that the sale of elephant ivory (even locally) was no longer legal. It thus appears that the local ivory market operates with little reference to the status of elephants in the wild. The ivory is not carved in Kandy, although Kandy is one of the main tourist destinations and the home of a number of elephants in captivity. These latter include some of the best tuskers, which are used in the Esala Perahera-an annual Buddhist pageant, during which up to 100 elephants accompany the regal tusker carrying the casket containing the sacred tooth relic of Buddha in a procession every night for a week in Kandy in July or August. The centre of ivory carving is Galle in the south of the island. Almost all the people interviewed named Galle as the place where most of the remaining ivory craftsmen still work. Furthermore, ivory carving is being done mainly by members of the Navandhana caste. Some members of the armed forces based in the vicinity of elephant ranges are also alleged to be the main suppliers of raw elephant ivory in Sri Lanka today. The ongoing civil war provides a cover for their activities. Tusks have also been smuggled out 
Table 1 Number of shops selling ivory products and fake-ivory products in Sri Lanka in 1997

\begin{tabular}{ll}
\hline City & No. of shops \\
\hline Negombo & 22 \\
Colombo & 15 \\
Beruwela & 14 \\
Hikkaduwa & 10 \\
Galle & 16 \\
Kandy & 7 \\
Anuradhapura & 2 \\
Total & 86 \\
\hline
\end{tabular}

Source: Department of Wildlife Conservation, Colombo, Sri Lanka.

of the conflict areas in the north and east of the island to India in fishing boats. This was discovered 3 years ago when a boat carrying refugees to India was taken into custody by the Sri Lanka Security Forces. Thus, international trade in ivory still continues illegally between Sri Lanka and India, although on a much reduced scale.

\section{Impact of the CITES ban}

Before the listing of African elephants in Appendix I of CITES in 1989, raw ivory in Sri Lanka used to cost Rs8000-10,000 (\$US228-285) per kg, according to shopkeepers dealing with ivory. Today the price has fallen to about Rs4000 (\$US72) per kg, indicating the very low demand for ivory on the island. Foreign tourists, with the possible exception of Italians, have largely refrained from buying ivory products following the international outcry against the ivory trade. Local trade in ivory products, which is not covered by CITES, still continues in Sri Lanka, with even fake-ivory carvings being sold to unsuspecting tourists. Cattle bone, elephant thigh bone, sambar antler and even fish bone are carved and sold as elephant ivory. In one instance a local plant (the

Table 2 Retail prices for various ivory items in Sri Lanka in 1997

\begin{tabular}{lc}
\hline Item & Price (\$US)* \\
\hline Ring & 2 \\
Pendant $(25 \times 25 \mathrm{~mm})$ & 8 \\
Letter opener $(125 \mathrm{~mm})$ & 9 \\
Buddha statue $(75 \mathrm{~mm}$ tall) & 18 \\
Beaded necklace $(40-50 \mathrm{~mm}$ long) & 65 \\
Cutwork elephant & 90 \\
Ganesha statue $(75 \mathrm{~mm}$ tall) & 90 \\
Ganesha statue $(125 \mathrm{~mm}$ tall) & 165 \\
Elaborately carved tusk (whole) & 2275 \\
Jewelled ivory elephant sculpture & 9000 \\
\hline
\end{tabular}

* Exchange rate $\$$ US1 $\equiv \mathrm{R}_{\$} 58$, April 1997.

Source: present survey. name of which was not divulged), whose stem becomes white when dried, was carved and sold as elephant ivory. Even local trade in ivory products could influence the international trade if it involves foreign tourists smuggling small ivory artefacts out of the country.

\section{Conclusion}

Although the Asian elephant was protected 60 years ago in Sri Lanka, and listed by CITES in Appendix I in 1975, it was the listing of the African elephant in Appendix I in 1989 that seemed to have had the most adverse effect on the ivory industry in Sri Lanka. Attitudes of educated local people and responsible tourists towards ivory products and elephants have changed so much in recent years that the demand for ivory products has declined substantially in Sri Lanka. Nevertheless, elephants are still being killed for their tusks in Sri Lanka and we cannot assume that some people will stop poaching elephants simply because the scientific evidence currently available indicates that such an offtake is unsustainable.

A tusker is worth more alive than dead: its value to the country's economy remains high through ecotourism. At present, a magnificent tusker could cost up to Rs1,500,000 (\$US23,000; Chin et al., 1998; de Silva, 1998). Elephants are status symbols in Sri Lanka and many people, especially the nouveaux riches, try to buy them. The long-term goal of elephant conservation in Sri Lanka must be to ensure the survival of viable populations as a basis for protected-area management and nature tourism. Given the rarity of tuskers in Sri Lanka, promotion of trade in ivory products within the island may lead to the elimination of the remaining tuskers. A local publicity campaign is needed urgently to alert people to the seriousness of the situation facing the few tuskers that are left and the need to eliminate the local trade in ivory products. At the same time publicity on a global scale is needed to influence the demand for ivory in Asia, where, for centuries, ivory has been part of art and cultural tradition. Already negative publicity and international trade bans on ivory appear to have worked in India: 'foreign tourists', according to Vigne (1991), 'no longer want or dare to buy ivory, except perhaps for the tiny pieces of jewellery and miniature paintings on ivory, which are easily hidden'. It remains to be seen what impact the change in listing, from Appendix I to Appendix II, at the 10th Meeting of the Parties to CITES in June 1997, of the African elephant populations of Botswana, Namibia and Zimbabwe will have on the trade in ivory in countries such as Sri Lanka, where tuskers are few and most vulnerable. 


\section{References}

Anon. (1996) Now, elephant-tusk hunters in NCP. The Island (Sri Lanka), 14 January 1996.

Baker, S. (1853) The Rifle and the Hound in Ceylon. Reprint edn, 1970. Tisara Prakasakyo, Dehiwela, Sri Lanka.

Clark, A. (1901) Sport in the Low-country in Ceylon. Reprint edn, 1971. Tisara Prakasakyo, Dehiwela, Sri Lanka.

Chin, H.C., Kumara, P.K.S., Piyadasa, W., Ganegoda, G.A.P. \& Perera, V.H. (1998) Domesticated working elephants in Sri Lanka. Paper presented at the First National Symposium of Elephant Management and Conservation, 29-30 May 1998, Colombo, Sri Lanka.

Hendavitharana, W., Dissanayake, S., de Silva, M. \& Santiapillai, C. (1994) The survey of elephants in Sri Lanka. Gajah, 12, 1-30.

Hensoldt, H. (1895) A Buddhist mystery: the fate of Major Rogers. Monthly Literary Register, 3, 90.

van Heurn, F.C. (1929) Die Olifanten van Sumatra. Drukkerij Gerretsen, Den Haag

Jayewardene, J. (1994) The Elephant in Sri Lanka. The Wildlife Heritage Trust of Sri Lanka, Colombo.

Marshall, H. (1846) Ceylon: a General Description of the Island and its Inhabitants. Reprint edn, 1969. Tisara Prakasakyo, Dehiwela, Sri Lanka.

Martin, C.P. \& Martin, E.B. (1990) Sri Lankan ivory sculpture in retrospect. Pachyderm, 13, 35-38.

Ramakrishnan, U., Santosh, J.A., Ramakrishnan, U. \& Sukumar, R. (1998) The population and conservation status of Asian elephants in the Peryiyar Tiger Reserve, Southern India. Current Science, 74(2), 110-113.
Santiapillai, C. (1994) Elephant mortality in Sri Lanka. Gajah, $12,48-54$.

de Silva, M. (1998) Status and conservation of the elephant (Elephas maximus) and the alleviation of man-elephant conflict in Sri Lanka. Gajah, 19, 1-68.

Storey, H. (1907) Hunting and Shooting in Ceylon. Reprint edn, 1969. Tisara Prakasakyo, Dehiwela, Sri Lanka.

Tennent, J.E. (1867) The Wild Elephant and the Method of Capture and Taming it in Ceylon. Longmans, Green \& Co, London.

Vigne, L. (1991) The collapse of India's ivory industry. Pachyderm, 14, 28.

Wanigasundara, M. (1990) Elephants slaughtered in civil war. The Jakarta Post (Indonesia), 1 November 1990.

\section{Biosketch}

As the Deputy Chairman of the IUCN/SSC Asian Specialist Group, Charles Santiapillai's chief interest is the conservation and management of the Asian elephant Elephas maximus. Other research studies in Asia concern the estimation of age at death through the study of layering in the cementum of the molar teeth of large herbivorous mammals such as wild buffalo Bubalus bubalis, banteng Bos javanicus, sambar Cervus unicolor, spotted deer Axis axis, wild pig Sus scrofa and feral ass Equus africanus. He also edits Gajah - the journal of the Asian Elephant Specialist Group. 